\title{
Foam-Resilient Distillation Processes-Influence of Pentosan and Thermal Energy Input on Foam Accumulation in Rye Mash Distillation
}

\author{
Daniel Heller ${ }^{1}\left[\right.$ ] Daniel Einfalt ${ }^{1}$
}

Received: 6 February 2021 / Accepted: 3 May 2021 / Published online: 20 May 2021

(c) The Author(s) 2021

\begin{abstract}
Foaming of mashes during distillation is a common problem encountered in spirit drink production. It has a negative impact on the purity of the final product. This research article presents the key aspects of foam accumulation in rye mashes during distillation. Foam accumulation was influenced by substrate characteristics and process parameters. The experiments showed that pentosan levels and thermal energy input were the crucial parameters for foam accumulation in rye mashes. Foam accumulation was significantly enhanced by higher pentosan levels, due to the higher viscosity imparted by pentosan. Hence, degradation of pentosans prior to distillation presents a way to reduce foam accumulation. In terms of thermal energy input, foam accumulation was significantly lower when the thermal energy input was reduced from 400 to $200 \mathrm{~W} / \mathrm{L}$. Substantial foaming only occurred in a narrow temperature range of 89.5 to $98.2 \mathrm{C}$. The results allowed for the first time to make recommendations to prevent problematic foam accumulation during distillation of rye mashes.
\end{abstract}

Keywords Foam $\cdot$ Distillation $\cdot$ Rye mash $\cdot$ Pentosan $\cdot$ Spirit drink production

\section{Introduction}

Excessive foam accumulation is a common cause for malfunctions and process failures in various technological processes. It regularly occurs in food and beverage industries and in chemical processing (agitation, distillation) (GallegoJuárez et al., 2015; Hilberer \& Chao, 2012; Nguyen et al., 2000; Schramm \& Wassmuth, 1994). In spirit drink distillation, excessive foam accumulation can lead to increased maintenance costs and impaired product quality (Miller, 2019; Pieper et al., 1977). In extreme cases, it can even cause plant flooding, resulting in the necessity of a partial or complete process shut down (Miller, 2019). To avoid such process interferences, it is important to gain excessive information on foam accumulation mechanisms during distillation.

The main reasons for impairing foam accumulations in industrial distillation processes are the utilisation of

Daniel Heller

daniel.heller@uni-hohenheim.de

1 Institute of Food Science and Biotechnology, Yeast Genetics and Fermentation Technology, University of Hohenheim, Garbenstraße 23, 70599 Stuttgart, Germany substrates with high foam formation capacities, inadequate operational process management, and technical faults (Kister, 2003). It is likely that similar factors apply to batch distillation processes of spirit drinks.

In order to understand the mechanisms that promote foam accumulations, it is important to investigate substrate properties supporting the formation of foam during distillation. Specific substrate properties with stabilising effects on foam formation have already been investigated in various food products. It is known that the presence of proteins and polysaccharides play an important role on the physical stability and structure of food foams (Dickinson, 1998, 2003; Nunes \& Coimbra, 1998; Prins, 1988; Ye, 2008). Therefore, we hypothesised that the presence of proteins and polysaccharides might also be important for foam accumulation in the distillation processes.

The spirits industry utilises various different fruits and cereals. All substrates have specific protein and polysaccharide contents and different foam formation capacities. So far, the literature only provides descriptive information on foam formation capacities of different fermented mashes. Enhanced foam formation capacities are known for cherry, wine lees and cereal mashes (Pieper et al., 1977). Within cereal substrates, rye mashes are especially prone to an 
excessive formation of foam (Pieper et al., 1977). Rye is known to contain higher concentrations (7 to $8 \mathrm{wt} \%$ ) of the nonstarch polysaccharide pentosan compared to other cereals with 1.4 to $4.1 \mathrm{wt} \%$ (Autio, 2006), which might influence foamformation properties. Pentosan mainly consist of arabinoxylan chains made out of 50 to $60 \%$ xylose and 30 to $35 \%$ arabinose (Belitz \& Grosch, 1999). In the bakery industry, pentosan is known to have a positive effect on dough network formation and loaf volume (Cawley, 1964; Denli \& Ercan, 2001; Maeda \& Morita, 2006; Vanhamel et al., 1993). Such dough and bread structures are often characterised by their gas-holding capacities and, therefore, have similar properties as classical foam structures (Izydorczyk et al., 1991). As pentosan supports the foam structure in doughs, it is possible that the presence of pentosan might also enhance the formation of foam during distillation.

Next to substrate properties, process management can drive foam formation. Scientific knowledge on foam accumulations related to operational management of distillation processes is still scarce. Simon et al., (2009) investigated the dependency of reboiler vessel size and vapour flow rate on reboiler vessel swelling (foam accumulation). Further, literature only provides descriptive information on process management strategies that reduce the risk of impairing foam accumulations. This includes recommendations to run batch distillations with a 25 to $50 \%$ reduced reboiler vessel filling to provide sufficient space for accumulating foams and to use a reduced thermal energy input at 'critical foam-prominent temperature ranges' (no further details given) (Pieper et al., 1977). However, in extreme cases, plant flooding occurred despite the implemented process management strategies (Pieper et al., 1977; Simon et al., 2009).

A common strategy for dealing with excessive foam accumulation is the application of chemical additives, which are usually based on silicone oil. These additives effectively reduce or prevent undesired foam accumulations after addition of 2 to $4 \mathrm{~g} / \mathrm{hL}$ mash (Denkov et al., 2014; Pieper et al., 1977). However, these 'antifoam additives' are known to have negative environmental effects when released to aquatic systems, e.g. interfere with oxygen transfer rates in water bodies and metabolic activities of microorganisms or impair biodegradation processes (Routledge et al., 2014). They also reduce catalytic activities in downstream processes (Rocker et al.,2011). As environmental regulations become more stringent, alternative foam control methods need to be employed. Therefore, it is important to understand foam accumulation mechanisms on substrate and process level to be able to prevent foam formation.

The aim of the study was to minimise foaming in spirits production with a substrate that is especially prone to foaming. Therefore, the present study investigated foam accumulations in rye mash distillation in regard to substrate and process parameters. It examined the relation of different pentosan concentrations as well as thermal energy input levels on foam accumulation during the process.

\section{Material and Methods}

\section{Mash Preparation}

Coarsely ground winter hybrid rye meal (RW S1 1363, HYBR 2012), grown and harvested in Lundsgaard, Germany, was provided by the Federal Plant Variety Office of Germany. Rye mash preparation was carried out according to Fig. 1. Rye meal and water were mixed in a 1:4 mass ratio. Calcium hydroxide (Merck KGaA, Darmstadt, Germany) and sulphuric acid (Carl Roth GmbH \&Co. $\mathrm{KG}$, Karlsruhe, Germany) were used for $\mathrm{pH}$ adjustment. To investigate the influence of pentosan, the pentosandegrading enzyme pentosanase EX-Tosan (C. Schliessmann Kellerei-Chemie GmbH \& Co.KG, Schwäbisch Hall, Germany) was applied during mash preparation. Enzymatic liquefaction was performed with Distiztym BA-TS (Erbslöh GmbH, Geisenheim, Germany) and added in concentrations of $0.066 \mathrm{~mL} / \mathrm{kg}$ rye meal. Enzymatic saccharification was carried out with an enzyme mixture consisting of $0.27 \mathrm{~mL}$ Distizym AG-Alpha (Erbslöh GmbH, Geisenheim, Germany) and $0.1 \mathrm{~g}$ Tegaclast 220P (tegaferm Holding GmbH, Vienna, Austria) per kilogram rye meal.

\section{Substrate Characterisation}

Fermented rye mashes were characterised for dry matter (DM), ash, pentosan, protein and ethanol content, while rye meal was investigated for fermentable substances (FS). DM and ash were determined according to VDLUFA (1997) and ICC (1960), respectively. Quantification of pentosan was performed according to AOAC (1960). The method was modified as described by Jäger and Unger (1902). Protein (N $\times 5.83$ ) content analysis was conducted using sample sizes of $100 \mathrm{mg}$ and a nitrogen analyser (Dumatherm, Gerhardt $\mathrm{GmbH} \&$ Co. KG, Königswinter, Germany) according to Duma's combustion method (AGF 1999). Ethanol content was determined via lab-scale steam distillation (Autodest 10, Leo Kübler GmbH, Karlsruhe, Germany) of $50 \mathrm{~g}$ mash samples (Senn \& Pieper, 1996). The density of distillates was analysed via u-tube-oscillator (DMA 4500 M, Anton Paar GmbH, Ostfildern, Germany).

Determination of FS in rye meal was carried out according to Senn and Pieper (1996). They defined FS as 'the sum of glucose and maltose contents of the raw material, calculated as starch, that can be determined using HPLC after the raw material is completely digested and dispersed as well as 


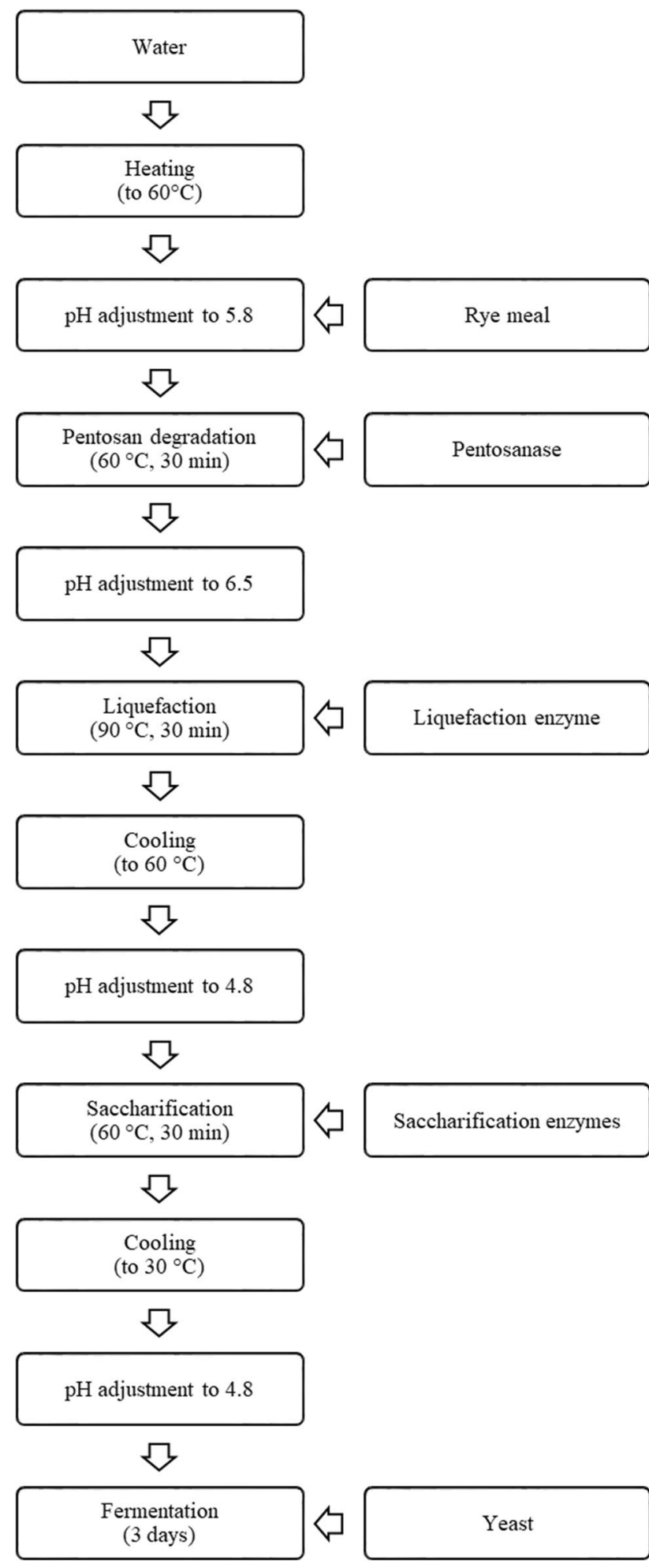

Fig. 1 Flow chart of rye mash preparation

liquified and saccharified by addition of technical enzymes'. The method was modified by additionally determining fructose contents and adding it to the FS calculation in Eq. (1).
$F S(w t \%)=\frac{\left(\varphi_{g}\left(C_{g}+C_{f}\right)+\varphi_{m} C_{m}\right) V_{S}}{W_{r m}} \times 100$,

where $\varphi_{\mathrm{g}}$ is the hydrolysis factor for glucose and fructose (0.899) and $\varphi_{\mathrm{m}}$ for maltose (0.947), $\mathrm{C}_{\mathrm{g}}, \mathrm{C}_{\mathrm{f}}$ and $\mathrm{C}_{\mathrm{m}}$ are concentrations of glucose, fructose and maltose $(\mathrm{g} / \mathrm{L}), \mathrm{V}_{\mathrm{S}}$ is the sample's end volume (L) and $\mathrm{W}_{\mathrm{rm}}$ is the initial mass of rye meal $(\mathrm{g})$.

The HPLC system for sugar analysis was set up with a Rezex RPM-Monosaccharide $\mathrm{Pb}+2$ Ion exclusion column ( $7.8 \times 300 \mathrm{~mm}$, Phenomenex, Aschaffenbug, Germany) and a refractive index detector (RID, Shodex RI-101, Thermo Fisher, Waltham, USA) with sulphuric acid $(0.005 \mathrm{~N})$ as eluent at a flow rate of $0.6 \mathrm{~mL} / \mathrm{min}$. Five-point standard calibration was used for fructose, glucose and maltose $\left(R^{2}>0.95\right)$.

\section{Pentosan Degradation Effects}

To determine the influence of pentosan on rye mash properties, nine different pentosanase concentrations $(0.0 ; 0.1 ; 0.2$; $0.8 ; 1.0 ; 1.2 ; 1.6 ; 2.0 ; 4.0 \mathrm{~mL} / \mathrm{kg}$ rye meal) were applied and investigated in triplicates for converted pentosan, mash viscosity and unspecific protein degradation. The same sample set was also used for studies on foam accumulation.

For the determination of converted pentosan, the pentosan hydrolysis products xylose and arabinose were quantified via 5 -point standard calibrated $\left(R^{2}>0.95\right)$ HPLC-RID analysis before pentosan degradation and after the saccharification step of the rye mash preparation. The conversion of pentosan to xylose and arabinose was calculated by Eq. (2) including the hydrolysis factor of $0.88\left(\varphi_{\mathrm{x}}\right)$ for xylose and arabinose.

pentosan conversion $(\%)=\frac{\varphi_{x}\left(C_{x}+C_{a}\right)-\left(C_{x 0}+C_{a 0}\right)}{C_{p 0}} \times 100$

where $C_{x}$ and $C_{a}$ are final concentrations of xylose and arabinose $(\mathrm{g} / \mathrm{L})$ after saccharification and $\mathrm{C}_{\mathrm{x} 0}, \mathrm{C}_{\mathrm{a} 0}$ and $\mathrm{C}_{\mathrm{p} 0}$ are initial concentrations of xylose, arabinose and pentosan before pentosan degradation $(\mathrm{g} / \mathrm{L})$.

Effects of pentosan degradation on mash viscosity were determined using a rotational rheometer (MC1, Paar Physica, Ostfildern, Germany) equipped with a double gap measuring system. Viscosities were measured with rye mash supernatants centrifuged at $2000 \mathrm{rpm}$ for $1 \mathrm{~min}$.

To exclude secondary activities of pentosanase in terms of additional unspecific protein degradation, an additional experiment was set up that added pentosanase in different concentrations of $0.0,0.1,0.2,0.8,1.6,2.0$ and $4.0 \mathrm{~mL} / \mathrm{kg}$ to $10 \mathrm{wt} \%$ protein solutions (Wheat Protein Isolate, Carl Roth GmbH, Karlsruhe, Germany) in citrate buffer. Protein blanks with each tested enzyme concentration were 
equally prepared. All samples and blanks were incubated for $1 \mathrm{~h}\left(60^{\circ} \mathrm{C}\right.$; $\left.\mathrm{pH} 5.8\right)$, and the remaining protein concentrations were determined by Bradford test (Bradford, 1976).

Additionally, SDS-PAGEs (Laemmli, 1970) of the rye mash samples with $0.0,0.1,0.2,0.8,1.6,2.0$ and $4.0 \mathrm{~mL} / \mathrm{kg}$ pentosanase addition were carried out to identify changes in the protein composition by analysis of their molecular masses with and without pentosan degradation.

\section{Foam Accumulation Experiments}

The first set of distillation experiments focussed on foam accumulation in rye mash distillation in regard to the nine different pentosan-degraded rye mashes. All rye mashes were distilled with a constant energy input of $200 \mathrm{~W} / \mathrm{L}$. In the second set of experiments, the influence of thermal energy input level was evaluated by distilling an additional sample set of nine different pentosan-degraded rye mashes with an energy input of $400 \mathrm{~W} / \mathrm{L}$.

Distillation experiments were conducted using a small-scale distillation plant set up. The dimension of the experimental setup corresponded to the dimensions of a standard distillery plant with $150 \mathrm{~L}$ reboiler vessel size and rectification column in a scale of 1:10. Mashes were electrically heated (LabHeat, SAF Wärmetechnik GmbH, Mörlenbach, Germany) in a 250-mL two-necked roundbottom flask (CN ST 29/32, SN ST 19/26, Lenz Laborglas $\mathrm{GmbH} \& \mathrm{Co}$. KG, Germany). Accumulating foam heights were logged every $60 \mathrm{~s}$ in a $34-\mathrm{cm}$ high, 32-mm wide glass tube (ST 29/32, Lenz Laborglas GmbH \& Co. KG, Wertheim am Main, Germany) equipped with a metric scale. Mash temperature was measured simultaneously with a thermometer (Testo 735 PT100, Testo SE \& Co. KGaA, Titisee-Neustadt, Germany) inserted into the side neck of the glass flask. The term 'foam accumulation' was defined for foam levels $>3 \mathrm{~cm}$.

\section{Statistical Analysis}

A total of 54 mashes were analysed for substrate characteristics and foam accumulations. The sample set included triplicate analysis of nine different pentosan-degraded rye mashes, distilled with two different energy inputs. Results are given in mean values with standard deviation. Significant differences $(p \leq 0.05)$ were evaluated by one-way ANOVA with Tukey HSD post hoc tests and performed with SPSS software (Version 25, IBM, USA). Pearson's correlation coefficients $(r)$ were analysed to identify the relation between pentosanase addition and pentosan conversion rate or mash viscosity.

\section{Results and Discussion}

\section{Substrate Characteristics}

The substrate characteristics of the rye mash are shown in Table 1. The investigated rye meal had a FS content of $60.1 \pm 0.1 \mathrm{wt} \%$ based on fresh matter (FM) $(n=3)$. The analysed substrate composition of the mashes was in accordance with the results of Hansen et al. (2004), who found similar pentosan, protein and ash contents. The fermented mashes contained ethanol concentrations of $6.2 \pm 0.6 \%$ vol. This showed that $51.5 \pm 5.1 \%$ of the FS was metabolised to ethanol, which indicated an efficient and complete fermentation.

\section{Pentosan Conversion}

Additions of pentosanase did result in increasing levels of the hydrolysis products arabinose and xylose. This indicated an efficient enzymatic conversion of pentosan. In comparison to the control mash, a significant increase of pentosan conversion was achieved with pentosanase concentrations $\geq 0.2 \mathrm{~mL} / \mathrm{kg}$. The Pearson correlation revealed a significant positive relationship between the pentosan conversion rate and the amount of added pentosanase $(r=0.99, p \leq$ $0.05)$. Pentosanase concentrations of $4.0 \mathrm{~mL} / \mathrm{kg}$ resulted in the highest pentosan conversion rate of $66.8 \pm 6.3 \%$. A conversion rate of $33.1 \pm 0.9 \%$ was also observed in the control sample without added pentosanase. This could be due to unspecific secondary activities of liquefaction and saccharification enzymes on pentosan degradation during mash preparation.

\section{Effects of Pentosan Conversion on Mash Viscosity}

The addition of pentosanase resulted in a decrease of mash viscosity (Fig. 2). The decrease in viscosity was proportional to the degree of pentosan conversion up to $42 \%$ of converted pentosan. Further degradation of pentosan did not result in a substantial decrease of viscosity, indicating a threshold of mash viscosity minimum. The reason for this behaviour

Table 1 Substrate characteristics of rye mash

\begin{tabular}{lcl}
\hline Properties & Values & Replicates \\
\hline DM (\%FM) & $7.0 \pm 0.1$ & 54 \\
Ash (\%DM) & $4.1 \pm 0.4$ & 54 \\
Pentosan (\%DM) & $22.8 \pm 0.8^{\mathrm{a}}$ & 6 \\
Protein (\%DM) & $21.5 \pm 0.1$ & 54 \\
Ethanol (\%vol) & $6.2 \pm 0.6$ & 54 \\
Ethanol yield (mL/kg rye) & $309.5 \pm 30.6$ & 54 \\
pH value & $4.1 \pm 0.1$ & 54 \\
\hline
\end{tabular}

${ }^{\mathrm{a}}$ Value based on control mash $(0.0 \mathrm{~mL} / \mathrm{kg}$ pentosanase addition $)$ 
Fig. 2 Maximum foam accumulation levels (primary $y$ axis) and viscosity (secondary $y$ axis) of nine rye mashes in relation to pentosan conversion ( $x$ axis), added pentosanase from left to right: $0.0,0.1,0.2,0.8,1.0,1.2$, $1.6,2.0$ and $4.0 \mathrm{~mL} / \mathrm{kg}(n=3)$

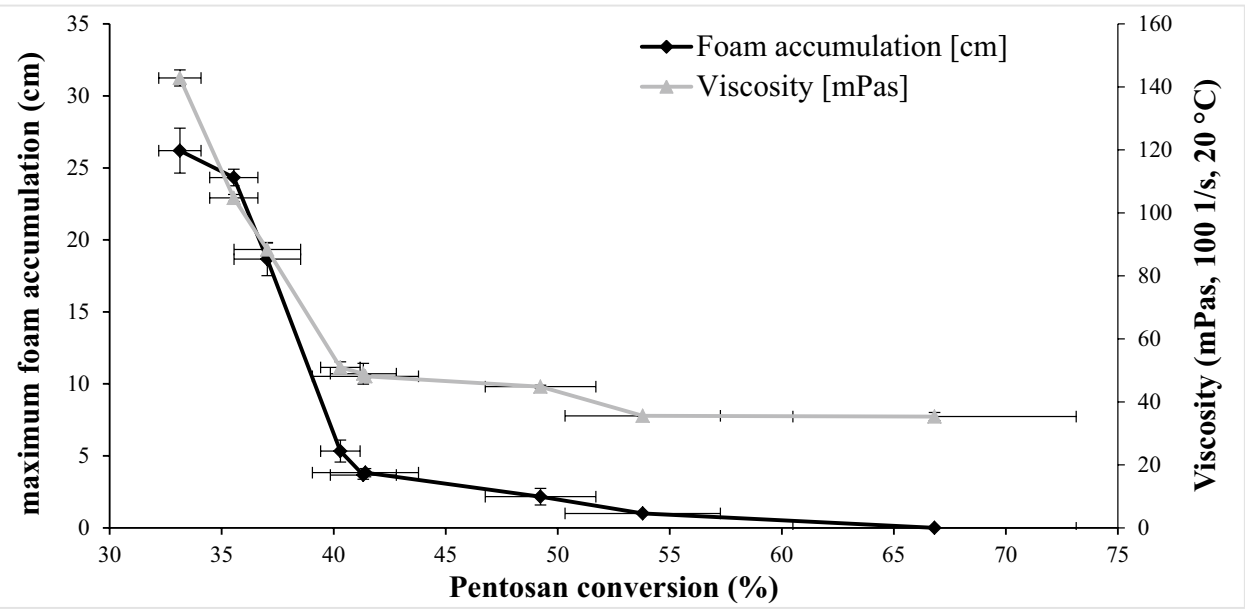

could be the two pools of pentosan. First, the soluble pool consisting mostly of arabinoxylans with the ability to form a highly viscous solution in water at a relatively low concentration (Bengtsson \& Aman, 1990), which are quickly degraded leading to a steep decline in viscosity. Second, the insoluble pool associated with insoluble particles, which due to its insolubility and particulate state does not contribute to the viscosity of the mash. In any case, the mash viscosity could be reduced by a factor of 4 by pentosanase treatment.

\section{Effects of Pentosan Conversion on Foam Accumulation}

We then determined the foam-forming capacity of the rye mashes at a constant energy input of $200 \mathrm{~W} / \mathrm{L}$ (Fig. 2). The control mash without added pentosanase showed maximal foam accumulation $(26.2 \pm 1.5 \mathrm{~cm})$. With increasing pentosanase concentrations and thus concomitant reduction of viscosity, the foam height was reduced. A strong decrease to $18.6 \pm 1.2 \mathrm{~cm}$ and $5.3 \pm 0.8 \mathrm{~cm}$ was observed when pentosanase was added in concentrations of $0.2 \mathrm{~mL} / \mathrm{kg}$ and $0.8 \mathrm{~mL} /$ $\mathrm{kg}$, respectively. Latter resulted in a significant reduction of the maximum foam accumulation level by $79.4 \%$ compared to the control. A complete inhibition of foam formation was achieved with addition of $4.0 \mathrm{~mL} / \mathrm{kg}$ pentosanase. These results indicate that pentosan concentrations have a major influence on foam accumulations. Further a clear correlation was observed between the viscosity of the mashes and the height of the foam $(r=0.98, p \leq 0.05)$. Similar linear correlations between foam-forming ability and viscosity were also reported in other alcoholic beverages like (sparkling) wine and beer (Brissonnet \& Maujean, 1991; Evans et al., 1999; Lewis \& Lewis, 2003; Marchal et al., 2003).

Polysaccharides are known to contribute to structural and textural properties of foams. They have a significant impact on the interlamellar liquid and the air/water interface by acting as steric stabilisers, thickening or gelling agents
(Dickinson, 2003; Prins, 1988; Sarker et al., 1998). An increase in the interlamellar liquid viscosity leads to reduced drainage of foam films and thus stabilised foams (Evans et al., 1999; Sarker et al., 1998). It is likely that degradation of the polysaccharide pentosan to its monosaccharides arabinose and xylose impairs such foam-stabilising properties resulting in reduced longevity and limited accumulation of foam bubbles. Our results on rye mash viscosity are in favour of this theory. A positive correlation between foam stability and the presence of arabinoxylans, like pentosan, was also noted in the study of Evans et al., (1999). Further, it was reported that arabinoxylans prevent the expansive destruction of gas bubbles under thermal conditions $\left(95^{\circ} \mathrm{C}\right)$ (Izydorczyk et al., 1991). However, the investigation of Meuser et al. (2001) indicated contradictory results. They reported only a minor foam reduction and physically stabilised foams after addition of pentosanase. The reason for this discrepancy could be that these experiments were performed at lower temperatures (between 5 and $35^{\circ} \mathrm{C}$ ).

\section{Unspecific Protein Degradation}

We also considered the possibility that foam reduction by pentosanase could also be due to side activities of the enzyme. For instance, unspecific protease activity may lead to the degradation of proteins, which could also result in a reduction of viscosity and foaming ability. To rule out this possibility, Bradford tests of protein solutions with different pentosanase addition and SDS-PAGEs of the rye mash proteins were performed. No significant changes in the protein concentrations and protein banding patterns were observed after addition of pentosanase to protein solutions and the rye mashes, respectively. Therefore, we assumed that unspecific secondary degradation effects of pentosanase can be excluded. We concluded that the degradation of pentosan was the main cause for the reduction of mash viscosity and, in-terms, foam formation. 


\section{Effects of Thermal Energy Input on Foam Accumulation}

Energy input levels had a major effect on foaming. With an energy input of $400 \mathrm{~W} / \mathrm{L}$, the maximum foam height of the experimental setup with $34 \mathrm{~cm}$ was exceeded within all experimental conditions, independently of pentosanase addition (Fig. 3). With $200 \mathrm{~W} / \mathrm{L}$, the maximum foam height was $26.2 \pm 1.5 \mathrm{~cm}$. The influence of thermal energy input on foam accumulation can be explained by a temperature-dependent increase in the gas vaporisation rate resulting in enhanced foam bubble formation. It can be concluded that energy input levels have a more severe effect on foam accumulation during distillation than the pentosan concentration of the rye mashes.

\section{Critical Temperature Range}

The temperature range in which foam formation occurs during the distillation of rye mashes has so far not been investigated. This study provides for the first time experimental data that defines the temperature range in which rye mash foaming occurred. A summary of heat-related foam formation of all distillation experiments is shown in Fig. 4. The first mash foam formation appeared at a mash temperature of $63.2^{\circ} \mathrm{C}(0.5$ to $3 \mathrm{~cm}$ foam level height). Substantial foaming $(>3 \mathrm{~cm})$ was observed at mash temperatures above $89.5^{\circ} \mathrm{C}$, while the highest level of foaming occurred between 91.2 and $94.5^{\circ} \mathrm{C}$. When mash temperatures exceeded $95.2^{\circ} \mathrm{C}$ the accumulated foams began to collapse and a steep decrease in foam accumulation was observed. At $98.2^{\circ} \mathrm{C}$ no foam accumulation $>3 \mathrm{~cm}$ could be observed. This showed that increasing mash temperatures
Fig. 3 Maximum foam accumulation levels in rye mash distillation performed with different thermal energy inputs and different pentosanse concentrations $(n=3)$
Fig. 4 Foam accumulation levels and mash temperature during distillation of 54 rye mashes, grey line indicates $3 \mathrm{~cm}$ foam level
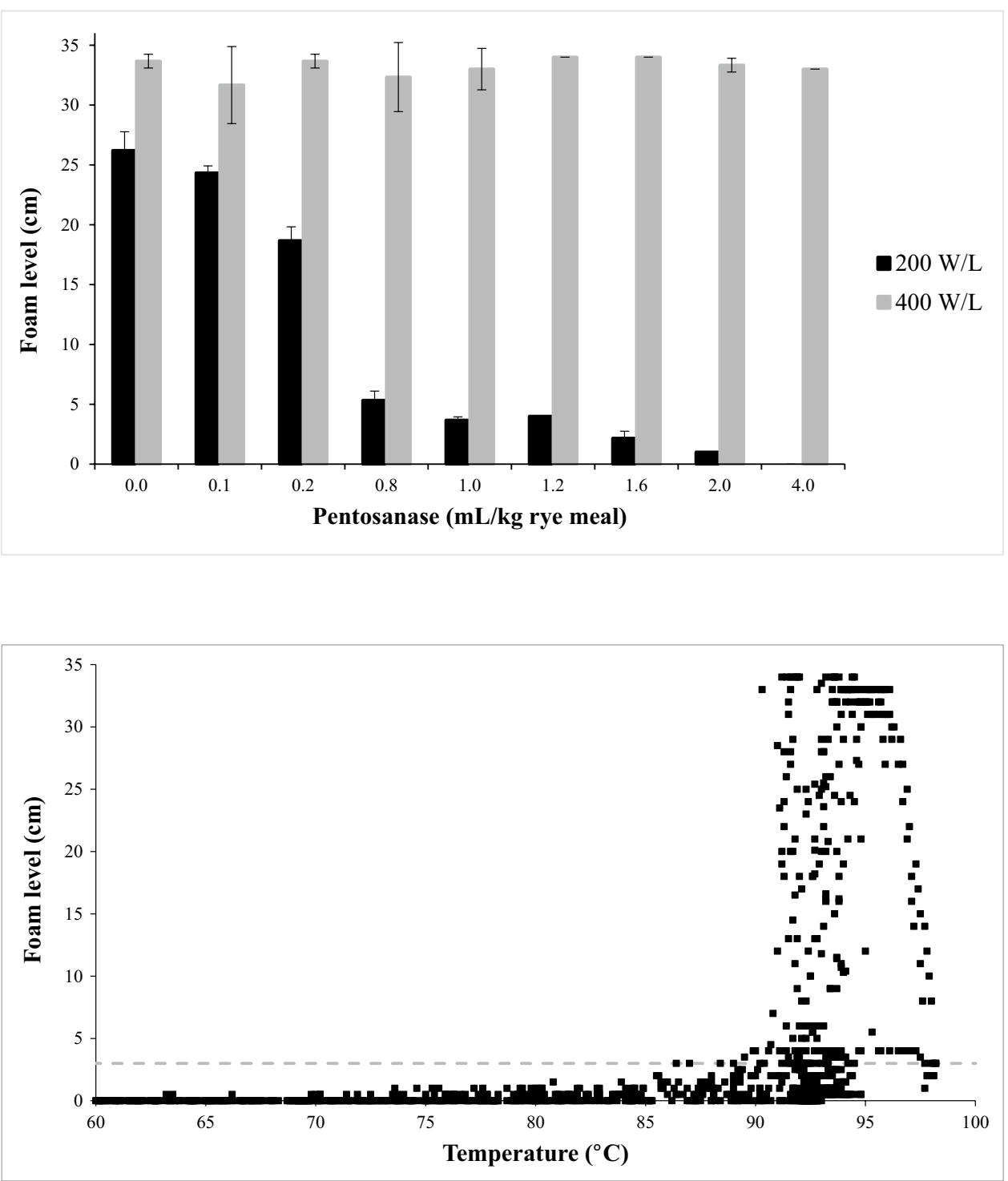
indeed triggered foam formation and induced foam collapse above a certain threshold temperature. The data set enables the definition of a foam critical temperature range during distillation. $90 \%$ of the foam accumulation occurs in the temperature range from 89.5 to $98.2{ }^{\circ} \mathrm{C}$. This temperature range can be defined as the most critical in terms of excessive foam accumulations and possible process impairments.

\section{Conclusion}

The investigation identified mechanisms of foam accumulations on substrate and process level. On substrate level, pentosan degradation had a major impact on mash viscosity and foam accumulation. A significant inhibition of foam accumulations can be achieved by addition of pentosandegrading enzymes during rye mash preparation.

On process level, foam accumulations were significantly dependent on energy input. Reduced energy inputs of $200 \mathrm{~W} / \mathrm{L}$ have the potential to lower the risk of the process of impairing foam accumulations. The main foam accumulation occurred only in a narrow temperature range. The experimental data offer the opportunity to define foam-resilient distillation parameters. We propose the following procedure to minimise the risk of foaming. The distillation process can be initiated with high energy input (e.g. $400 \mathrm{~W} / \mathrm{L}$ ) until the critical mash temperature $\left(89.5^{\circ} \mathrm{C}\right.$ for rye mash) is reached. Then the thermal energy input is reduced to $200 \mathrm{~W} / \mathrm{L}$. After reaching a mash temperature of $98.2{ }^{\circ} \mathrm{C}$, a higher-energy input level can again be restored. Pentosanase treatment of the rye mash is highly recommended. In a next step, the obtained data can be used for a validation of foam-resilient processes in industrial distillation plants.

Funding Open Access funding enabled and organized by Projekt DEAL. This work was supported by The German Federation of Industrial Research Associations (AiF) within the programme Industrial Collective Research for SMEs (IGF) [AiF 4 PN].

Data Availability The data that support the findings of this study are available from the corresponding author, Daniel Heller, upon reasonable request.

Code availability Not applicable.

\section{Declarations}

Conflict of interest The authors declare no conflict of interest.

Open Access This article is licensed under a Creative Commons Attribution 4.0 International License, which permits use, sharing, adaptation, distribution and reproduction in any medium or format, as long as you give appropriate credit to the original author(s) and the source, provide a link to the Creative Commons licence, and indicate if changes were made. The images or other third party material in this article are included in the article's Creative Commons licence, unless indicated otherwise in a credit line to the material. If material is not included in the article's Creative Commons licence and your intended use is not permitted by statutory regulation or exceeds the permitted use, you will need to obtain permission directly from the copyright holder. To view a copy of this licence, visit http://creativecommons.org/licenses/by/4.0/.

\section{References}

AGF. (1999). Bestimmung des Proteingehaltesmittels DUMASVerbrennungsmethode: Standardmethode der Arbeitsgemeinschaft Getreideforschung e.V. Detmold.

A Hilberer SH Chao 2012 Antifoaming agents. In encyclopedia of polymer science and technology (Vol. 21, pp. 60-65). John Wiley \& Sons, Inc. https://doi.org/10.1002/0471440264.pst411. pub2

AOAC. (1960). Official methods of analysis of the Association of Official Agricultural Chemists.

Autio, K. (2006). Functional aspects of cereal cell-wall polysaccharides. In Carbohydrates in food, second edition (pp. 167-207). CRC Press. https://doi.org/10.1201/9781420015058.ch5

Belitz, H.-D., \& Grosch, W. (1999). Food chemistry (3rd ed.). Springer Berlin. https://doi.org/10.1007/978-3-662-07281-3

Bengtsson, S., \& Aman, P. (1990). Isolation and chemical characterization of water-soluble arabinoxylans in rye grain. Carbohydrate Polymers, 12(3), 267-277. https://doi.org/10.1016/ 0144-8617(90)90068-4

Bradford, M. M. (1976). A rapid and sensitive method for the quantitation of microgram quantities of protein utilizing the principle of protein-dye binding. Analytical Biochemistry, 72(1-2), 248-254. https://doi.org/10.1016/0003-2697(76)90527-3

Brissonnet, F., \& Maujean, A. (1991). Identification of some foamactive compounds in a Champagne base wine. American Journal of Enology and Viticulture, 42(2), 97-102

Cawley, R. W. (1964). The role of wheat flour pentosans in baking. II.-Effect of added flour pentosans and other gums on glutenstarch loaves. Journal of the Science of Food and Agriculture, 15(12), 834-838. https://doi.org/10.1002/jsfa.2740151204

Denkov, N. D., Marinova, K. G., \& Tcholakova, S. S. (2014). Mechanistic understanding of the modes of action of foam control agents. Advances in Colloid and Interface Science, 206, 57-67. https://doi.org/10.1016/j.cis.2013.08.004

Denli, E., \& Ercan, R. (2001). Effect of added pentosans isolated from wheat and rye grain on some properties of bread. European Food Research and Technology, 212(3), 374-376. https:// doi.org/10.1007/s002170000281

Dickinson, E. (1998). Stability and rheological implications of electrostatic milk protein-polysaccharide interactions. Trends in Food Science \& Technology, 9(10), 347-354. https://doi.org/ 10.1016/S0924-2244(98)00057-0

Dickinson, E. (2003). Hydrocolloids at interfaces and the influence on the properties of dispersed systems. Food Hydrocolloids, 17(1), 25-39. https://doi.org/10.1016/S0268-005X(01)00120-5

Evans, D. E., Sheehan, M. C., \& Stewart, D. C. (1999). The impact of malt derived proteins on beer foam quality. Part II: the influence of malt foam-positive proteins and non-starch polysaccharides on beer foam quality. Journal of the Institute of Brewing, 105(3), 171-178. https://doi.org/10.1002/j.2050-0416.1999. tb00016.x

Gallego-Juárez, J. A., Rodríguez, G., Riera, E., \& Cardoni, A. (2015). Ultrasonic defoaming and debubbling in food processing and other applications. In power ultrasonics (pp. 793-814). Elsevier. https://doi.org/10.1016/B978-1-78242-028-6.00026-0 
Hansen, H. B., Møller, B., Andersen, S. B., Jørgensen, J. R., \& Hansen, A. (2004). Grain characteristics, chemical composition, and functional properties, of rye (Secale cereale L.) as influenced by genotype and harvest year. Journal of Agricultural and Food Chemistry, 52(8), 2282-2291. https://doi.org/10.1021/jf0307191

ICC-International Association for Cereal Science and Technology.(1960). 104/1 Determination of Ash in Cereals and Cereal Products.

Izydorczyk, M., Biliaderis, C. G., \& Bushuk, W. (1991). Physical properties of water-soluble pentosans from different wheat varieties. Cereal Chem., 68(2), 145-150. https://www.aaccnet.org/ publications/cc/backissues/1991/Documents/CC1991a30.html. Accessed 21 Apr 2021.

Jäger, R., \& Unger, E. (1902). Ueber Pentosanbestimmung. Berichte Der Deutschen Chemischen Gesellschaft, 35(4), 4440-4443. https://doi.org/10.1002/cber.190203504106

Kister, H. Z. (2003). What caused tower malfunctions in the last 50 years? Chemical Engineering Research and Design, 81(1), 5-26. https://doi.org/10.1205/026387603321158159

Laemmli, U. K. (1970). Cleavage of structural proteins during the assembly of the head of bacteriophage T4. Nature, 227(5259), 680-685. https://doi.org/10.1038/227680a0

Lewis, M., \& Lewis, A. (2003). Correlation of beer foam with other beer properties. Master Brewers Association of the Americas, $40(2), 114-124$

Maeda, T., \& Morita, N. (2006). Characteristics of pentosan in polished wheat flour and its improving effects on breadmaking. Journal of Applied Glycoscience, 53(1), 21-26. https://doi.org/10.5458/ jag.53.21

Marchal, R., Descoins, C., \& Jeandet, P. (2003). Effect of the temperature on the Champagne wine foaming properties. In Vino Analytica Sciencia Congress. Aveiro, Portugal.

Meuser, F., Busch, K. G., Fuhrmeister, H., \& Rubach, K. (2001). Foamforming capacity of substances present in rye. Cereal Chemistry, 78(1), 50-54. https://doi.org/10.1094/CCHEM.2001.78.1.50

Miller, G. H. (2019). Whisky Science. Springer International Publishing. https://doi.org/10.1007/978-3-030-13732-8

Nguyen, Q. P., Alexandrov, A. V., Zitha, P. L., \& Currie, P. K. (2000). Experimental and modeling studies on foam in porous media: a review. Society of Petroleum Engineers. https://doi.org/10.2118/ 58799-MS

Nunes, F. M., \& Coimbra, M. A. (1998). Influence of polysaccharide composition in foam stability of espresso coffee. Carbohydrate Polymers, 37(3), 283-285. https://doi.org/10.1016/S01448617(98)00072-1
Pieper, H. J., Bruchmann, E.-E., \& Kolb, E. (1977). Technologie der Obstbrennerei. Eugen Ulmer GmbH \& Co.

Prins, A. (1988). Principles of foam stability. In E. Dickinson \& G. Stainsby (Eds.), Advances in food emulsions and foams. (pp. 91-122). Elsevier Applied Sience.

Rocker, J., Mahmoudkhani, A., Bava, L., \& Wilson, B. (2011). Low environmental impact nonsilicone defoamers for use in oil/gas/ water separators. Society of Petroleum Engineers. https://doi.org/ 10.2118/149462-MS

Routledge, S. J., Poyner, D. R., \& Bill, R. M. (2014). Antifoams: the overlooked additive? Pharmaceutical Bioprocessing, 2(2), 111114. https://doi.org/10.2217/PBP.14.5

Sarker, D. K., Wilde, P. J., \& Clark, D. C. (1998). Enhancement of protein foam stability by formation of wheat arabinoxylan-protein crosslinks. Cereal Chemistry, 75(4), 493-499. https://doi.org/10. 1094/CCHEM.1998.75.4.493

Schramm, L. L., \& Wassmuth, F. (1994). Foams: basic principles. In Foams: fundamentals and applications in the petroleum industry (Vol. 242, pp. 3-45). https://doi.org/10.1021/ba-1994-0242.ch001

Senn, T., \& Pieper, H. (1996). Ethanol-classical methods. In H. Rehm \& G. Reed (Eds.), Biotechnology - products of primary metabolism. (Vol. 6, pp. 109-110). VCH.

Simon, L. L., Kencse, H., \& Hungerbuhler, K. (2009). Optimal rectification column, reboiler vessel, connection pipe selection and optimal control of batch distillation considering hydraulic limitations. Chemical Engineering and Processing: Process Intensification, 48(4), 938-949. https://doi.org/10.1016/j.cep.2008.12.006

Vanhamel, S., Cleemput, G., Delcour, J. A., Nys, M., \& Darius, P. L. (1993). Physicochemical and functional properties of rye nonstarch polysaccharides. IV. The effect of high molecular weight water-soluble pentosans on wheat-bread quality in a straightdough procedure. Cereal Chemistry. https://www.aaccnet. org/publications/cc/backissues/1993/documents/70_306. pdf. Accessed 21 Apr 2021.

VDLUFA. (1997). Method Book III - The chemical analysis of feedstuffs (3.). VDLUFA Verlag.

Ye, A. (2008). Complexation between milk proteins and polysaccharides via electrostatic interaction: Principles and applications - a review. International Journal of Food Science and Technology, 43(3), 406-415. https://doi.org/10.1111/j.1365-2621.2006. 01454.x

Publisher's Note Springer Nature remains neutral with regard to jurisdictional claims in published maps and institutional affiliations. 